\title{
Scots pine's capacity to adapt to climate change in hemi-boreal forests in relation to dominating tree increment and site condition
}

\author{
Marius Mikalajūnas ${ }^{(1)}$, \\ Hans Pretzsch ${ }^{(2)}$, \\ Gintautas Mozgeris ${ }^{(1)}$, \\ Edgaras Linkevičius ${ }^{(1)}$, \\ Ingrida Augustaitiené ${ }^{(1)}$, \\ Algirdas Augustaitis ${ }^{(1)}$
}

\begin{abstract}
Forest site (FS) and meteorological conditions are recognized as the main factors affecting tree growth and whole-stand sustainability. This study aims to detect the combined effects of FS and meteorological conditions on tree ring formation of Scots pine (Pinus sylvestris L.), the most common tree species in Lithuania and hemi-boreal forests of northeastern Europe. We used data on stand structure and productivity from the Lithuanian National Forest Inventory (NFI) and stem radial increment series of dominating trees during the period 1993-2012 collected since 2013. Pine stem basal area increment (BAl) was chosen as the response variable, while temperature in March $\left({ }^{\circ} \mathrm{C}\right)$ and precipitation in June $(\mathrm{mm})$ were used as predictor variables, as they best express the effect of climate change on Lithuanian forests. We simulated the effects on dominating pine annual increment of deciduous tree species, mainly Betula sp. and the level of soil moisture and fertility, accounting in addition for the random effects of NFI network tract, plot direction, and tree number. A nonlinear mixed-effects model explained up to $68 \%$ of the variation in the BAl of pine trees. The annual pine trees BAl increased with the increase in the proportion of deciduous trees in pine stands. Increases in temperature and precipitation in considered months reinforced this positive effect on pine BAl, especially in mature pine stands in temporarily waterlogged meso-eutrophic FSs on mineral soils. A negative effect of deciduous trees on pine stem increment was observed only in nutrient-rich eutrophic and drained peatland FSs. Forestry treatments directed towards the increase in deciduous tree proportion in the most common normal or temporarily waterlogged meso-eutrophic and oligotrophic pine stands might increase the biodiversity and productivity of pine stands, and their sustainability in future climate change scenarios.
\end{abstract}

Keywords: Scots Pine, Basal Area Increment, Site Conditions, Meteorology, Mixed-effects, Hemi-Boreal Forests

expected to increasingly impact forest ecosystems (Bouwman et al. 2021), as it could affect forest area, health and biodiversity. On one hand, climate change may increase growth rates in temperate and boreal forests (Mensah et al. 2021), while on the other hand, temperature-induced drought stress can endanger the survival of trees and forest communities (Pretzsch et al. 2013, Toochi 2017, Pretzsch 2020), especially in southernmost areas (RubioCuadrado et al. 2020). In northeastern europe, such changes are expected to have a positive influence on boreal forest growth with an increase in productivity. However, the impact of climate warming in the hemiboreal zone, which is the transition zone between boreal and temperate zones, depends on site conditions (Matisons et al. 2021). Such divergent forest productivity trends challenge our capability to effect projections of tree growth dynamics under the pressures of climate change (Ols et al. 2019).

The impact of climate change on productivity varies according to geographic area, species, stand composition, tree age, soil fertility and water holding capacity, as well as the interactions of these parameters
(McMillan et al. 2008, Reich \& Oleksyn 2008, Ols et al. 2019). Therefore, forest site-specific conditions like soil moisture and fertility can be key factors limiting tree growth (Forrester \& Albrecht 2014). However, our understanding of the effects of climate on forest health, productivity, and the carbon cycle is limited for many regions and ecosystems, especially under different or opposite site conditions (Spiecker 1999, Nellemann \& Thomsen 2001, Chapagain \& Sharma 2021). Usually, such observations are based on small sample sizes, which makes it difficult to extrapolate them to the regional or national forest scale (Sharma et al. 2019). The influence of species mixing on the reaction of pine to environmental change needs more detailed investigation, especially in different site conditions (Aldea et al. 2021, Chapagain \& Sharma 2021).

Tree responses to climate change have been analyzed in relation to soil conditions (Reich \& Oleksyn 2008). Tree rings are widely used to study the impact of climate change on forest carbon cycling, and for validating process-based models of forest productivity where temporal variation are determined by large trees (Xu et al. 2019). 
Understanding the effects of climate change on forest productivity and its time series is critical, and tree rings offer an annually resolved proxy to explore tree growth over times when no forest inventories or meteorological instrumental records were available (Cook \& Kairiukstis 1990). Tree-ring series are widely used to reconstruct stand productivity history. Therefore, the impact of climate change on forest tree growth, as well as past growth trends (Macias et al. 2006, Piovesan et al. 2008) have been extensively analyzed through series of tree rings (Girardin et al. 2008, Garant et al. 2009), especially of dominating trees in forest stands (Xu et al. 2019).

Scots pine (Pinus sylvestris L.) was chosen in this study as the main species to detect the effect of increased temperature and precipitation on tree annual increment. It is one of the most common tree species not only in Lithuania but also in the entire hemi-boreal and boreal european region (Pretzsch et al. 2015). Our earlier findings in northeastern Lithuania revealed that since 1980 Scots pine trees showed significant increases in annual basal area increment (BAI). This was related to significant longterm increases in air temperature in September, early spring and July. Heat and drought in June limited pine tree growth, but only on organic soils under excessmoisture regime, which increased the sensitivity of pine to drought (Augustaitis 2007a, 2015, 2018).

In northeastern europe, air temperature and precipitation increased over the $20^{\text {th }}$ century and particularly since the late 1980 s (IPCC 2014, Augustaitis et al. 2018, Ols et al. 2019). Recently Lithuania became a top hotspot in Europe. There greatest shifts in thermal and precipitation regimes have been detected, with mean temperature increasing by $+0.325^{\circ} \mathrm{C}$ and precipitation by $+20 \mathrm{~mm}$ per decade (Schlechtriem 2019). The adaptation capacity of pine forests to such climate changes is one of the major challenges for forest management in this region. It is necessary to un- derstand the effects of climate change on pine growth to be able to predict how these effects might affect pine stand sustainability in hemi-boreal forests in the future. Recently, the proportion of deciduous tree, especially Betula spp. in pine stands, has also been shown to have a major effect on pine tree annual increment in relation to tree age, density and site condition (Aldea et al. 2021). In this study we attempted to determine and assess: (i) the effects of key meteorological parameters on pine tree annual BAI in forest sites with different levels of soil moisture and soil fertility; (ii) the effect of the proportion of deciduous trees in pine stands on pine annual BAI under different soil conditions; (iii): the effect of tree age on pine tree annual BAl under different forest site conditions in relation to selected meteorological parameters; (iv) future changes in pine tree annual BAI in hemi-boreal pine forests under forecasted climatic conditions.

The results could suggest new forestry treatments ensuring sustainable forest development under the pressures of global change in hemi-boreal forests.

\section{Materials and methods}

\section{National Forest Inventory data}

Data on stand, tree and soil characteristics were collected on the NFI plots during the fourth National Forest Inventory (NFI) 5-year cycle from 2013 to 2017 (Fig. 1). Scots pine cores were collected at breast height from one selected dominating tree of each tree species growing in the same stand, but outside of the permanently monitored plot. Annual increment of the dominating tree of each tree species in a stand was selected as the main response variable to detect the integrated effects of environmental predictor variables. The sample size for dendrochronological analysis during the entire 5-year cycle consisted of 2414 Scots pine trees over 40 years old from the same number of sample plots. More than 2500 cores were taken from other tree species.

We eliminated data on pine BAl from stands younger than 40 years to reduce variability in tree-ring width data, as the variability in younger stands is high due to tree competition and tree density (Kairiukstis et al. 1987, Schweingruber 1996, Juknys et al. 2002, 2003, De Vries et al. 2014).

Dendrometric parameters of trees were obtained from four circle plots $\left(500 \mathrm{~m}^{2}\right.$ in size and $12.76 \mathrm{~m}$ in radius) in each NFI tract, which were located on the tops of isosceles triangles at $4 \mathrm{~km}$ distance from each other both horizontally and vertically (Fig. 1). The identification of a tract and the position of a plot in the tract (direction), as well as the tree identification number (id) were used to account for random effects on pine BAl formation in mixed-effects models. Forest type and soil conditions were also assessed in the plots using the Lithuanian NFI methodology (Kuliešis et al. 2016).

\section{BAl calculation of sample dominating trees}

We measured annual tree-ring width in stem cores, from bark to pith, with an accuracy of $0.01 \mathrm{~mm}$, using an electronic transducer and a binocular scope fixed over the moving stage of the Lintab ${ }^{\text {TM }}$ v. 6 tree-ring measuring equipment, and TSAP$W_{i n}{ }^{T M}$ software (RinnTech e.K., Heidelberg, Germany). Individual tree-ring width series were synchronized by a visual comparison of graphs for each ring width series with averaged pine tree ring width series of the correct age group (Eckstein et al. 1989). We calculated the Pearson's correlation coefficients and means among and between each tree ring width series for the right age group (Baillie \& Pilcher 1973). This procedure ensured significant differences in annual increments among years, but synchronic and non-significant differences in the rhythm of growth in relation to tree diameter at different ages (Pretzsch 2020).

The data on tree ring widths over the last 5-year period (2013-2017) were not included in the analysis to avoid not fully formed increments of the last year to have equal period for each tree.

To detect recent regular pine tree

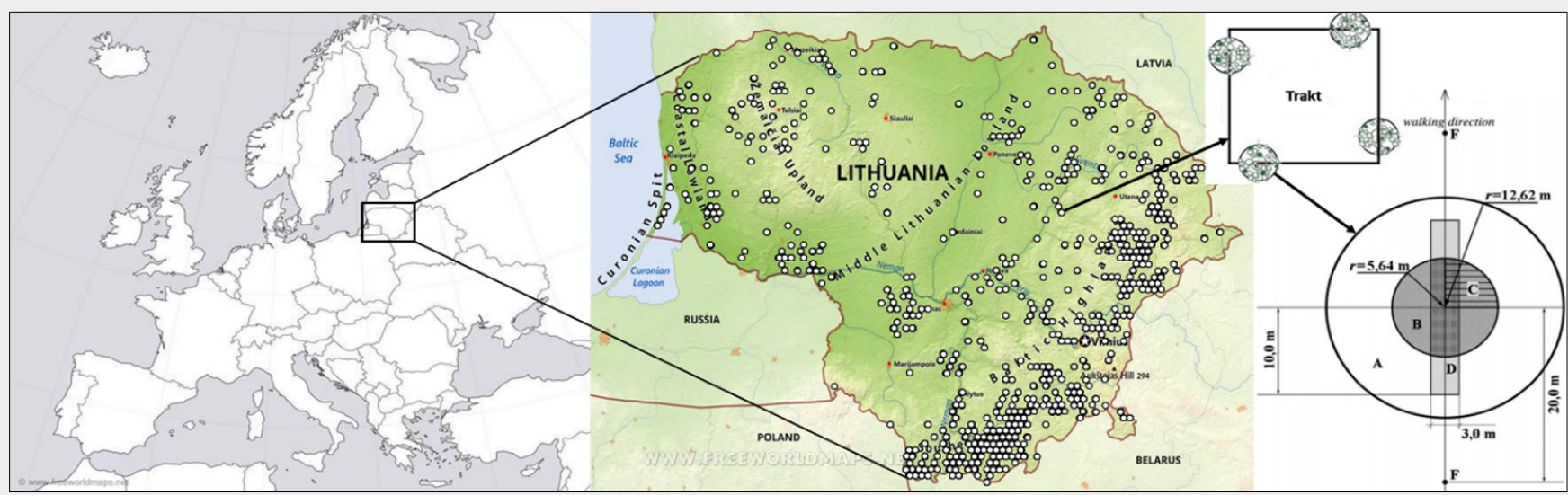

Fig. 1 - Location of Scots pine sample plots and structure of NFI permanent plots at $4 \mathrm{~km}$ distance from each other across Lithuania. The $250 \times 250 \mathrm{~m}$ tract with four $500 \mathrm{~m}^{2}$ circle plots at its different directions represents a plot. 
growth, the period between 1993 and 2012 was chosen for analysis (Fig. 2). This 20year period when mean temperature and precipitation increased by $0.049^{\circ} \mathrm{C}$ and 1.92 $\mathrm{mm}$ per year, respectively, (Augustaitis et al. 2018) reflects climate change quite well. This increase is statistically significant and is in full agreement with the SReS A1 B Project (IPCC 2014).

Basal area increment (BAI) series were derived from tree ring width series. BAl was used instead of ring width, due to its higher relationships with stem volume increment and lower interrelationship with tree diameter and tree ageing process, as well as recent tree age. This parameter captures growth trends better than treering width and avoids the need for data detrending (Biondi \& Qeadan 2008). Such detrending could also remove low frequency variability that could hide the effects of meteorological parameters with the same variability.

\section{Meteorological data}

Meteorological data were collected from 16 meteorological stations located across Lithuania. Mean monthly precipitation and temperature were used in the BAl analysis. Mean temperature in March and precipitation in June were chosen as they have the most significant effect on the pine increment not only in Lithuanian forests (Fig. 2) but also in boreal and hemi-boreal forests (Seidling et al. 2012). This is in agreement with our previous results (Juknys et al. 2003, 2014, Augustaitis et al. 2007b, 2015, 2018). Climatic parameters were assigned for each tree using an inverse distance weighted (IDW) interpolation method based on the distance to meteorological stations located nearby (Daly et al. 2002).

\section{Forest sites}

Scots pine responses to the considered meteorological parameters were analyzed based on growing conditions defined by a classification of stands into forest site types. These types describe edaphic and hydrological site conditions and are the main classification units used in Lithuanian forestry. In the present study, four forest sites (FS) differing in soil moisture and four FSs differing in soil fertility level were defined. Moisture regime of the FSs, defined in this study as "Water" independent variables, varied from normal moisture (W1) and temporary over moisture (W2) to drained (W3) and undrained peatland (W4). FS fertility level, defined in this study as "Nutrients" independent variables, varied from very oligotrophic (N4) and oligotrophic soils (N3) to mesoeutrophic (N2) and eutrophic soils (N1). This characterization of the monitored forest sites allowed us to detect the effects of soil properties on pine growth.

\section{Scots pine BAI modeling}

The linear mixed-effects (LMe) model from the R package "NLMe" (Pinheiro et al. 2018) was used to analyze differences in annual BAI under different soil conditions. Tract id, plot position in the tract, and tree id were included as random effects in all the models. An asterisk $\left(^{*}\right)$ in the model indicates interactions between the main group and the remaining three "Water" or "Nutrients" groups. The predict function in the R package "stats" v. 3.6.0 was used to display the model values with average group parameters.

BAl data logarithms (log) were used to remove heteroscedasticity from the model residuals and after the simulation were back-transformed to tree BAI using exponent function. Biological plausibility of the results was used to evaluate the model (Burnham \& Anderson 2002). All the statistical analyses were carried out using $R$ software (R Development Core Team 2018).

The BAI model in relation to the moisture regime of the FS referred to as "Water" is described as follows (Water model - eqn. 1):

$$
\begin{aligned}
& \log (B A I)=(\text { Water }) \\
& \cdot\left[T_{(I I I)}+P_{(V I)}+\log (\text { Mix })\right]+\log (B A)
\end{aligned}
$$

where $B A I$ is the basal area increment in year $t$. Fixed effects are composed of four soil moisture regime groups (Water: W1, $\left.W_{2}, W_{3}, W_{4}\right) ; T_{(I I I)}$ is the mean temperature in March; $P_{(\mathrm{VI})}$ is the sum of precipitations during June; Mix is the proportion of pine trees in the mixed pine stand, where 1 indicates a pure pine stand; and $B A$ is the tree basal area in year $t-1$, calculated from ring width.

An interaction comparison was performed on normal moisture sites (W1), which were the most common with $\mathrm{N}=1682$ trees. Where $p<0.05$ indicated significant differences between the effect of predicting variables on pine $\mathrm{BAl}$ in the main forest site and the rest FSs, while $p>0.05$ indicated no statistical differences of this effect, i.e., effect of predicting variables was the same like in the main selected forest site.

BAI model in relation to soil fertility level of FS is described as follows (Nutrient model - eqn. 2):

$\log (B A I)=($ Nutrients $)$

$$
\cdot\left[T_{(I I I)}+P_{(V I)}+\log (M i x)\right]+\log (B A)
$$

where $B A l$ is the basal area increment in year $t$. Fixed effects are composed of four "Nutrients" groups based on soil fertility level (Nutrients: N1, N2, N3, N4); $T_{(\text {(III) }}$ is the mean temperature in March; $P_{(\mathrm{VI})}$ is the sum of precipitation during June; Mix is the proportion of pine trees in the mixed pine stand; $B A$ is the tree basal area in year $t-1$, calculated from ring width.

Interactions between BAI and predict variables were compared to the mesotrophic site (N2) as this FS is not only quite represented in our sample, but is also the FS where the most productive pure pine stands could be developed in hemi-boreal coniferous forest.

In the present study, the effect of deciduous trees in pine stands is expressed as the proportion of pine trees in the pine stand ("Mix"), defined as (eqn. 3):

$$
\text { Mix }=1-\frac{D B A}{W S B A}
$$

where DBA is the basal area of deciduous trees in a pine stand; WSBA is the whole
Fig. 2 - Annual values of precipitation and temperature in Lithuania with added trends for the considered 20year period (left) and effect of their monthly values on changes in mean BAI values of all pine trees during the 20-year period (right).

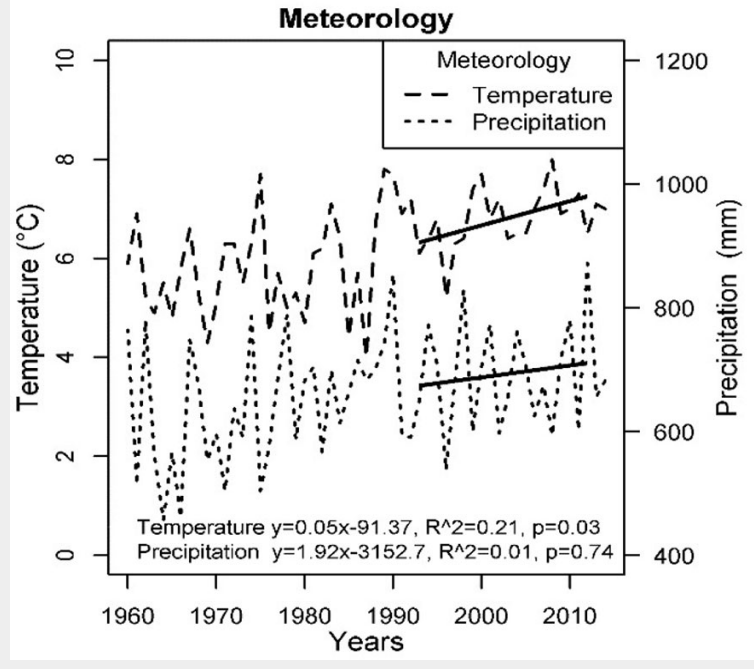


Tab. 1 - Mean stand characteristics of FSs in soil water and nutrients groups, and their core samples. (BAI): annual basal area increment for a 20 year period from 1993 to $2012\left(\mathrm{~cm}^{2}\right)$; (Age): stand age (year); (Mix): mean proportion of pine in the mixed pinedeciduous stand; $\left(\mathrm{Dbh}_{\text {plot }}\right)$ : mean diameter of trees at breast height $(1.3 \mathrm{~m})$ at a sample plot $(\mathrm{cm}) ;\left(\mathrm{H}_{\text {plot }}\right)$ : mean height of trees at a sample plot $(\mathrm{m})$; (Age_plot): age of the stand (years); (Cores): number of sampled trees selected for BAl estimation (units). Dbh and Age are the main characteristics of the sampled pine trees selected for BAl estimation. (*): Mean characteristics of pine stands obtained from NFI data base; (**): Mean characteristics from dominant in stand trees selected for BAl estimation.

\begin{tabular}{|c|c|c|c|c|c|c|c|c|c|c|}
\hline \multirow{2}{*}{$\begin{array}{l}\text { Data } \\
\text { set }\end{array}$} & \multirow{2}{*}{ Mean } & \multirow{2}{*}{ Unit } & \multicolumn{4}{|c|}{ Water } & \multicolumn{4}{|c|}{ Nutrients } \\
\hline & & & W1 & W2 & W3 & W4 & N1 & N2 & N3 & N4 \\
\hline \multirow{4}{*}{$\frac{\frac{*}{L}}{\frac{1}{z}}$} & $\mathrm{Dbh}_{\text {plot }}$ & $\mathrm{cm}$ & 28.9 & 29.2 & 24.4 & 14.8 & 29.4 & 30.2 & 28.1 & 21.3 \\
\hline & $\mathrm{H}_{\text {plot }}$ & $\mathrm{m}$ & 25.9 & 26.2 & 23.1 & 14.1 & 26.1 & 27.1 & 25.4 & 18.5 \\
\hline & Mix & - & 0.95 & 0.88 & 0.84 & 0.91 & 0.80 & 0.88 & 0.94 & 0.97 \\
\hline & Age & yrs & 85 & 85 & 90 & 88 & 83 & 81 & 87 & 85 \\
\hline \multirow{4}{*}{ 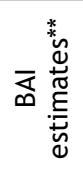 } & BAl & $\mathrm{cm}^{2}$ & 10.36 & 10.98 & 9.12 & 4.91 & 12.38 & 12.21 & 9.54 & 7.71 \\
\hline & Dbh & $\mathrm{cm}$ & 32.3 & 34.0 & 29.1 & 19.3 & 37.0 & 35.3 & 31.4 & 24.9 \\
\hline & Age & yrs & 77 & 78 & 81 & 87 & 74 & 74 & 80 & 77 \\
\hline & Cores & $\mathrm{n}$ & 1682 & 286 & 139 & 157 & 37 & 471 & 1464 & 292 \\
\hline
\end{tabular}

stand basal area.

To evaluate the effect of tree age on the relationships between pine BAl formation and meteorological variables in different mixed pine stands, data obtained in normal humid (W1), temporary waterlogged (W2), mesotrophic (N2), and oligotrophic ( $\left.\mathrm{N}_{3}\right)$ soil FSs were used. Very oligotrophic (N4) FS stands were excluded from this analysis due to the inadequacy of oligotrophic soils for the growth of deciduous trees. Three age groups were selected, each age group containing more than 200 samples of pine $\mathrm{BAI}$ series from the same pine stands. BAI model in relation to the selected tree age, referred to as "Age", is described as follows (Age model - eqn. 4):

$$
\begin{aligned}
& \log (B A I)=(\text { Age }) \\
& \cdot\left[T_{(I I I)}+P_{(V I)}+\log (\text { Mix })\right]+\log (B A)
\end{aligned}
$$

where the fixed effects are composed of Age, classified into three age groups (60-, 80-, and 110-year-old); $T$ and $P$ parameters, which are as defined above for the "Nutrients" and "Water" models. An interaction comparison was performed on the youngest 60-year age group.

Determination coefficients $\left(R^{2}\right)$ were used to evaluate the models. Marginal $\mathrm{R}^{2} \mathrm{de}-$ scribes the proportion of variance ex- plained by the fixed factors alone; conditional $R^{2}$ describes the proportion of variance explained by the fixed and random factors (Nakagawa \& Schielzeth 2013). The effects of fixed factors in the BAI model were evaluated using the level of significance $(p)$. Model estimate values were back-transformed using the "exp" function in $\mathrm{R}$.

\section{Results}

\section{Overall data evaluation}

The sampled trees for BAl estimation were distributed in different FS groups based on "Nutrients" and "Water" levels. The regular FS condition of pine stands in Lithuania is normal humid (W1) and oligotrophic soil (N3). These groups were the most represented in the study. Representation of the other FSs was lower (Tab. 1). Pine tree stands from drained peatland (W3) and eutrophic soil (N1) FSs were least represented in the study, because these FSs are less represented overall for pine growth in Lithuania. The most productive FSs were on temporally waterlogged soils (W2), and mesoeutrophic soils FS (N2).

BAl data reflect the productivity of the separate FS groups. The least productive pine stands grow on undrained peatland (W4) and very oligotrophic (N4) soils. Pine growth at these sites is extremely limited by an over-moisture regime and lack of nutrients compared to the other FSs. Only a few sampled pine trees represented eutrophic soil (N1) FSs, as these sites are mainly occupied by deciduous tree species and the pines growing there tend to form big crowns with large branches that ruin the overall wood quality and do not form pure stands. This FS is not typical of pine growth in a hemi-boreal forest.

Results from the ANOVA two-factor analysis of BAI variation indicated significant differences among the years over the considered 20-year period, as well as among four moisture and fertility FS groups (Fig. 3).

\section{Effect of meteorology on pine BAI for} different "Water" FS groups

The results showed that temperature in March had a significant effect on pine BAI variation at $\mathrm{W}_{1}$ forest sites (Tab. 2 - Water model, MT row). March temperature also had a positive effect on the other FSs. An increase in temperature by $1^{\circ} \mathrm{C}$ resulted in an increase of pine BAl in the different "Water" FS groups of $0.19 \mathrm{~cm}^{2}$ for $\mathrm{W}_{1}, 0.26$ $\mathrm{cm}^{2}$ for $W_{2}, 0.20 \mathrm{~cm}^{2}$ for $W_{3}$, and $0.07 \mathrm{~cm}^{2}$ for W4 (Fig. S1 in Supplementary material). The only significant difference was found between the effect of temperature on BAI in temporarily waterlogged (W2) vs. normal moisture (W1) FSs (Tab. 2 - W2:MT, p < 0.001).

Pine BAI in drained peatlands ( $\left.\mathrm{W}_{3}\right)$ and natural peatlands (W4) differed also from the normal moisture sites (W1) when the effect of temperature on BAl formation (Tab. 2) was accounted for, but only close to the level of significance ( $p<0.1-$ Fig. $S 1$ in Supplementary material).

The effect of June precipitation on pine BAl formation at W1 FS was also highly significant (Tab. 2 - Water model, JP row), but less significant than the effect of March temperature in other FSs. In $\mathrm{W}_{1}, \mathrm{~W}_{2}$ and $\mathrm{W}_{4} \mathrm{FSs}$, a $10 \mathrm{~mm}$ increase in precipitation increased BAl by $0.16 \mathrm{~cm}^{2}, 0.32 \mathrm{~cm}^{2}$ and $0.05 \mathrm{~cm}^{2}$, respectively. Precipitation in drained peatland soils (W3) had a negative effect on the BAl of $-0.26 \mathrm{~cm}^{2}$ per $10 \mathrm{~mm}$, significantly different from the effect of

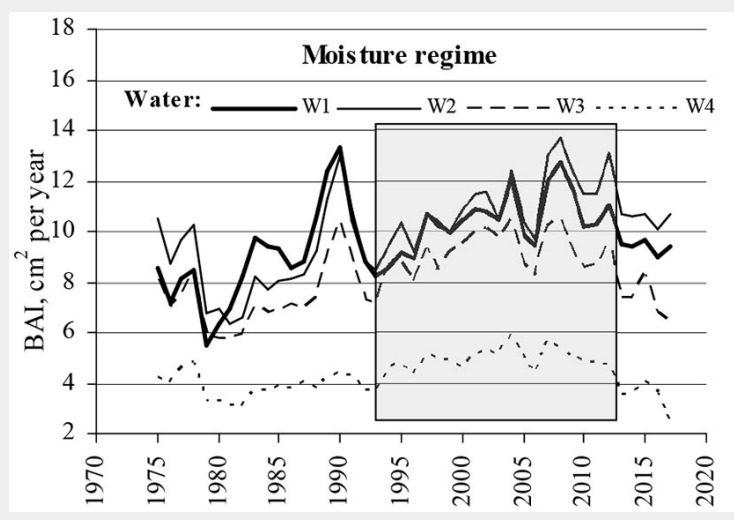

Fig. 3 - Annual basal area increment (BAI) of the sampled dominating pine trees in pine stands of different moisture and fertility levels. Shaded area indicates the 20-year period of investigation. 
Tab. 2 - Models' parameters and significance values of predicting variables. NFI tract, direction, and tree id were used as random effects. (MT): mean temperature in March; (JP): precipitation amount in June; (SD): standard deviation of the random effects. For more details on parameters, see text.

\begin{tabular}{|c|c|c|c|c|c|c|}
\hline \multirow{3}{*}{ Model } & \multicolumn{6}{|c|}{ Fixed effects } \\
\hline & \multirow{2}{*}{ Parameter } & \multirow{2}{*}{ Estimate } & \multicolumn{2}{|c|}{ Confidence interval (95\%) } & \multirow{2}{*}{ Std. Error } & \multirow{2}{*}{$\mathrm{p}$-value } \\
\hline & & & lower & upper & & \\
\hline \multirow[t]{17}{*}{ Water model } & Intercept & -0.124 & 0.112 & 0.137 & 1.053 & $<0.001$ \\
\hline & W2 & -0.919 & 0.834 & 1.013 & 1.051 & 0.089 \\
\hline & W3 & 1.134 & 0.976 & 1.317 & 1.079 & 0.101 \\
\hline & W4 & -0.71 & 0.62 & 0.815 & 1.072 & $<0.001$ \\
\hline & MT & 1.022 & 1.021 & 1.023 & 1.001 & $<0.001$ \\
\hline & $J P$ & 1 & 1 & 1 & 1 & $<0.001$ \\
\hline & $\log (\operatorname{Mix})$ & -0.701 & 0.55 & 0.896 & 1.133 & 0.005 \\
\hline & $\log (\mathrm{BA})$ & 3.687 & 3.586 & 3.791 & 1.014 & $<0.001$ \\
\hline & W2:MT & 1.007 & 1.004 & 1.01 & 1.002 & $<0.001$ \\
\hline & W3:MT & 1.004 & 1 & 1.009 & 1.002 & 0.071 \\
\hline & W4:MT & -0.996 & 0.992 & 1 & 1.002 & 0.069 \\
\hline & W2:JP & 1 & 1 & 1 & 1 & 0.186 \\
\hline & W3:JP & -0.999 & 0.999 & 1 & 1 & 0.003 \\
\hline & W4:JP & -0.999 & 1 & 1 & 1 & 0.769 \\
\hline & W2: $\log ($ Mix $)$ & -0.819 & 0.525 & 1.279 & 1.254 & 0.381 \\
\hline & W3: $\log ($ Mix $)$ & 2.851 & 1.577 & 5.153 & 1.352 & 0.001 \\
\hline & W4: $\log ($ Mix $)$ & -0.62 & 0.264 & 1.457 & 1.545 & 0.273 \\
\hline \multirow[t]{17}{*}{ Nutrients model } & Intercept & -0.106 & 0.095 & 0.119 & 1.122 & $<0.001$ \\
\hline & N1 & 1.29 & 0.947 & 1.757 & 1.171 & 0.106 \\
\hline & N3 & -0.999 & 0.921 & 1.084 & 1.043 & 0.99 \\
\hline & N4 & -0.986 & 0.882 & 1.102 & 1.059 & 0.803 \\
\hline & MT & 1.019 & 1.016 & 1.021 & 1.001 & $<0.001$ \\
\hline & $J P$ & 1.001 & 1 & 1.001 & 1 & $<0.001$ \\
\hline & $\log (M i x)$ & -0.694 & 0.513 & 0.938 & 1.166 & 0.018 \\
\hline & $\log (B A)$ & 3.84 & 3.736 & 3.948 & 1.034 & $<0.001$ \\
\hline & N1:MT & 1.003 & 0.995 & 1.012 & 1.004 & 0.568 \\
\hline & N3:MT & 1.005 & 1.003 & 1.008 & 1.001 & $<0.001$ \\
\hline & N4:MT & 1.003 & 0.999 & 1.007 & 1.002 & 0.114 \\
\hline & N1:JP & -0.999 & 0.999 & 1.001 & 1 & 0.592 \\
\hline & N3:JP & -0.999 & 0.999 & 1 & 1 & $<0.001$ \\
\hline & N4:JP & -0.999 & 1 & 1.001 & 1 & 0.002 \\
\hline & $\mathrm{N} 1: \log (\mathrm{Mix})$ & 2.509 & 0.924 & 6.812 & 1.665 & 0.072 \\
\hline & N3: $\log ($ Mix $)$ & 1.245 & 0.839 & 1.847 & 1.223 & 0.277 \\
\hline & $N 4: \log (M i x)$ & 1.343 & 0.562 & 3.212 & 1.56 & 0.507 \\
\hline \multirow[t]{13}{*}{ Age model } & Intercept & -0.088 & 0.071 & 0.11 & 1.238 & $<0.001$ \\
\hline & 80 & -0.964 & 0.848 & 1.097 & 1.068 & 0.582 \\
\hline & 110 & -0.841 & 0.737 & 0.96 & 1.07 & 0.011 \\
\hline & MT & 1.018 & 1.014 & 1.022 & 1.002 & $<0.001$ \\
\hline & $J P$ & 1.001 & 1 & 1.001 & 1 & $<0.001$ \\
\hline & $\log (\operatorname{Mix})$ & -0.565 & 0.359 & 0.889 & 1.257 & 0.014 \\
\hline & $\log (B A)$ & 4.109 & 3.885 & 4.345 & 1.068 & $<0.001$ \\
\hline & 80:MT & 1.003 & 0.998 & 1.008 & 1.003 & 0.297 \\
\hline & 110:MT & 1.005 & 1 & 1.011 & 1.003 & 0.041 \\
\hline & $80: J P$ & -0.999 & 1 & 1 & 1 & 0.85 \\
\hline & 110:JP & -0.999 & 0.999 & 1 & 1 & 0.229 \\
\hline & $80: \log (M i x)$ & 1.486 & 0.824 & 2.681 & 1.352 & 0.189 \\
\hline & 110:log(Mix) & -0.934 & 0.504 & 1.733 & 1.371 & 0.831 \\
\hline \multirow{2}{*}{ Model } & - & \multicolumn{3}{|c|}{ Random effects standard deviation } & \multicolumn{2}{|c|}{ Determination coeff. $\mathrm{R}^{2}$} \\
\hline & - & Tract id & Direction & Tree id & Marginal & Conditional \\
\hline Nutrients model & - & 1.261 & 1.238 & 1.395 & 0.29 & 0.658 \\
\hline Water model & - & 1.243 & 1.23 & 1.396 & 0.313 & 0.662 \\
\hline Age model & - & 1.325 & 1.205 & 1.419 & 0.25 & 0.644 \\
\hline
\end{tabular}


precipitation on $\mathrm{BAI}$ in the normal moisture regime $W_{1}$ (Tab. $2-W_{3}: J P, p<0.003$ ). For the other FSs, the effect of precipitation on BAI was positive, and did not differ significantly from the effect of precipitation in normal soil moisture sites $\mathrm{W}_{1}$ (W2:JP, $\mathrm{p}>$ 0.18 ) and especially in peatland soils (W4:JP, $p>0.76$ ).

The results on the "Intercept estimate" for $W_{2}, W_{3}$ and $W_{4}$ compared to group $W_{1}$ when the effect of the other variables in the model were eliminated (equal to 0 ) shows that BAI in the $\mathrm{W}_{1} \mathrm{FS}$ differed quite significantly from the other groups (Tab. 2 - lines $\left.W_{2}-W_{4}, p<0.01\right)$. The highest level of significance was between BAI in the $\mathrm{W}_{1}$ and W4 FSs $(p<0.05)$. Thus, the soil moisture regime modifies significantly the effect of the meteorological parameters on pine BAI. The integrated effect of meteorological and stand mixture parameters increased the significance among the BAI in different moisture FSs, explaining more than $66 \%$ of the variation.

Effect of meteorological conditions on pine BAl in different "Nutrients" FS groups

Both meteorological parameters also had a highly significant positive effect on pine $\mathrm{BAl}$ in main mesotrophic (N2) FS. An increase in March temperature by $1{ }^{\circ} \mathrm{C}$ resulted in an increase in pine $\mathrm{BAl}$ in all groups of "Nutrients" FSs, i.e., by $0.24 \mathrm{~cm}^{2}$ in $\mathrm{N}_{1}, 0.19 \mathrm{~cm}^{2}$ in $\mathrm{N} 2,0.20 \mathrm{~cm}^{2}$ in $\mathrm{N}_{3}$, and $0.13 \mathrm{~cm}^{2}$ in $\mathrm{N}_{4}$ (Fig. S2 in Supplementary material). The only significant difference was found between the effect of temperature on $\mathrm{BAI}$ in oligotrophic soils $\mathrm{N}_{3}$ and in mesotrophic soil N2 (Tab. 2 - N3:MT, p < 0.001). Quite different effect of temperature on BAI was found in very oligotrophic soils (N4) if compared with data obtained in (N2). Difference was close to the level of significance (N4:MT, $p>0.1$ ). No significant difference was found between the effect of temperature on BAI between eutrophic $\mathrm{N} 1$ (N1:MT, $p>0.5$ ) and mesoeutrophic soils N2. This means that March temperature had a similar significant effect on pine
BAl at both eutrophic (N1) and mesoeutrophic soils (N2) FSs.

Similar results were obtained for the effects of June precipitation on BAl at FSs with different nutrient levels. An increase in precipitation by $10 \mathrm{~mm}$ in June resulted in an increase in pine BAI in all groups of "Nutrients" FSs, i.e., by $0.36 \mathrm{~cm}^{2}$ for $\mathrm{N} 1$, $0.53 \mathrm{~cm}^{2}$ for $\mathrm{N} 2,0.06 \mathrm{~cm}^{2}$ for $\mathrm{N} 3$, and 0.03 $\mathrm{cm}^{2}$ for $\mathrm{N}_{4}$ (Fig. S2 in Supplementary material). No statistical difference was detected in the effect of precipitation on BAI between eutrophic $\mathrm{N} 1$ (N1:JP, $\mathrm{p}>0.5$ ) and mesoeutrophic soil N2. The effect of precipitation on BAl of pine trees growing in oligotrophic soils $\left(\mathrm{N}_{3}\right)$ and very oligotrophic soils (N4) FSs significantly differed from the effect of precipitation on BAI at mesotrophic (N2) FSs (Tab. 2 - N3:JP and $\mathrm{N} 4:$ : P, $\mathrm{p}<0.001)$ and also at eutrophic N1 FSs.

The results on the "Intercept estimate" for $N_{1}, N_{3}$ and $N_{4}$ compared to the FS N2 value when the effect of the other variables in model were eliminated (equal to 0 ) revealed that differences in BAl were not statistically significant among "Nutrients model" groups (Tab. 2 - lines N1-N4, $p$ > $0.05)$. This is in full agreement with the fact that Scots pine has lower demand for nutrients than for water. Further, significant differences in BAI in different nutrient soil conditions were found, mainly depending on age and interactions with meteorological and stand mixture parameters explaining up to $65 \%$ in BAl variation. The comparison between "water" and "nutrients" effects revealed that soil moisture was more important for pine BAI than soil nutrients if other parameters are constant.

\section{Effect of tree age on relationships}

between pine BAl formation and

meteorology in different FS groups

Both meteorological parameters had a significant and positive effect on the BAI of pine trees of ages varying between 40 to 70 years. Tree age had a significant effect on the relationship between temperature and BAI (Fig. $\mathrm{S}_{3}$ in Supplementary mate-

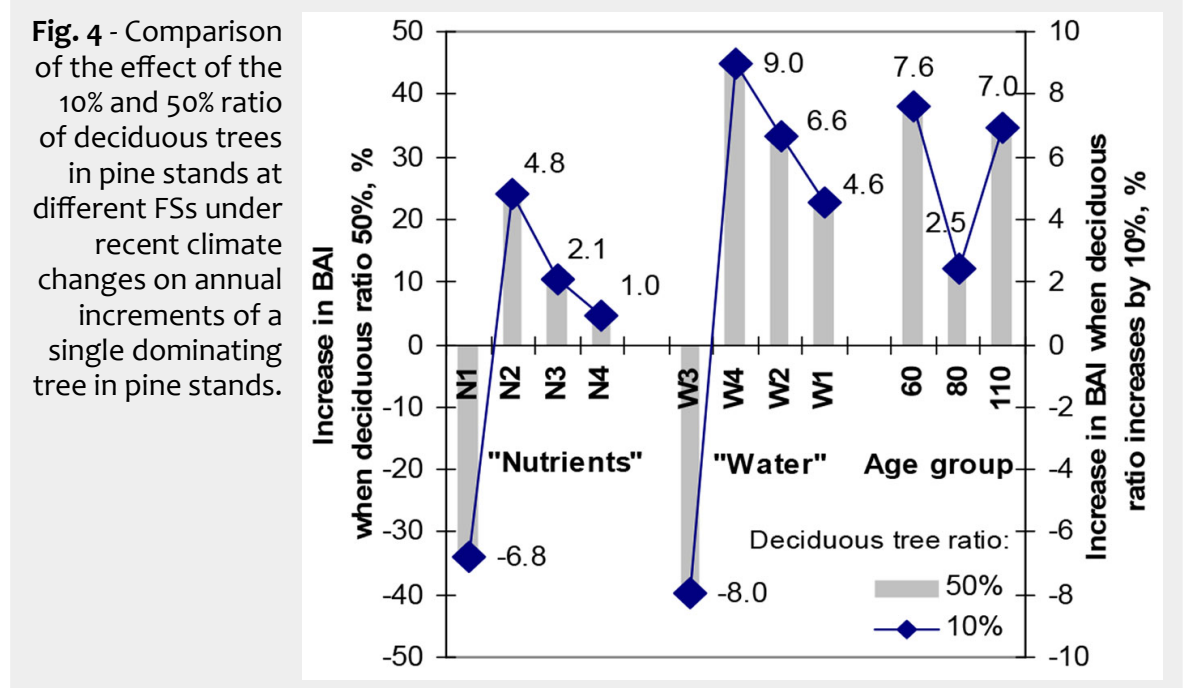

rial). An increase in temperature by $1^{\circ} \mathrm{C}$ resulted in an increase in pine BAl by $0.16 \mathrm{~cm}^{2}$ for 60 year old trees, $0.19 \mathrm{~cm}^{2}$ for 80 year old trees, and $0.23 \mathrm{~cm}^{2}$ for 110 year old trees (Fig. S2). There were no significant differences in the effect of temperature on the BAI of 70 to 90 year old trees, however, the effect on the BAl of trees over 100 years old was significant (Tab. 2 110:MT, $p<0.04$ ). The increase in temperature resulted in more intensive increase in BAls for mature or over-mature pine trees than for younger trees. It is the key finding of the effect of climate warming on pine BAI in hemi-boreal forests.

The effect of precipitation on BAI was also found to be positive, but tree age had no significant effect on these relationships (Fig. S3 in Supplementary material). Precipitation had the most effect on pine BAI in stand ages between 60 and 110 years, but this difference was not statistically significant (110:JP, $\mathrm{p}>0.2)$. We conclude that both temperature and precipitation had a positive effect on pine BAI, the effect varied with age classes, and in all cases, temperature had a stronger effect than precipitation.

The results on the intercept estimated for the 80- and 110-year age groups compared to the 60 year group when the effect of other variables in model were eliminated (equal to o) revealed that only differences between BAl from the first and third age group were significant. The obtained differences in BAI were found mainly depending on age and interactions, with meteorological and stand mixture parameters explaining up to $64 \%$ of BAl variation.

Effect of deciduous tree proportion in pine stands in different "Water" and "Nutrients" soil FSs and age groups

In this study the increase in deciduous tree proportion (DTP) in mixed pine stands (decrease in the "Mix" parameter, i.e., pine proportion in pine stand) also had a positive effect on BAl formation, but only in typical Scots pine FSs. The negative effect of deciduous trees was found only in forest stands on drained peatland soils $W_{3}$. For normal moisture $\mathrm{FSs}\left(\mathrm{W}_{1}\right)$, a 10\% reduction in pine proportion (increase in deciduous trees proportion) increased pine BAl by more than $0.5 \mathrm{~cm}^{2}$, while in drained peatland (W3) soil FSs decreased by almost 0.7 $\mathrm{cm}^{2}$ (W3: $\log (\mathrm{mix})$ - Tab. 2, Fig. S4). The relationships between other FSs ( $\mathrm{W}_{2}$ and W4) showed a similar positive increase in $\mathrm{BAI}$ when the pine mixing proportion decreased.

The relationship between BAI formation and proportion of pine in stands at mesotrophic soil (N2) FSs did not differ significantly from the relationships established in the other "Nutrients" FS groups, with the exception of the eutrophic N1 FS, where the effect of stand mixture on BAl was close to the level of significance $(p<0.07)$. There, a $10 \%$ decrease in pine proportion (increase in deciduous tree proportion) re- 
sulted in pine BAI increase by $0.63 \mathrm{~cm}^{2}$ in mesoeutrophic soil ( $\left.\mathrm{N}_{2}\right)$ while in eutrophic soils (N1) in BAl decrease by almost -0.9 $\mathrm{cm}^{2}$. At oligotrophic $\mathrm{N}_{3}$ and very oligotrophic N4, a $10 \%$ increase in deciduous trees proportion in pine stands increased pine BAI by $0.2 \mathrm{~cm}^{2}$ and $0.07 \mathrm{~cm}^{2}$, respectively. This effect of deciduous trees on pine BAI did not differ significantly from that detected in mesoeutrophic N2 FSs.

As the FS fertility decreased from mesotrophic to very oligotrophic soils, there was a clear decrease in the positive effect of deciduous trees on pine BAI. Pine trees growing in stands with a higher deciduous tree proportion (Fig. S4 in Supplementary material) had a higher BAI than pine trees growing in pure pine stands, especially at N2 FSs. The opposite effect on pine BAI was observed in eutrophic soils (N1). There, deciduous trees inhibited pine BAI formation. This site is not typical for Scots pine in hemi-boreal forests.

Tree age had no significant effect on the relationship between pine BAI and deciduous tree proportion in mixed pine stands. A $10 \%$ reduction in pine proportion in a stand (or increase in deciduous tree proportion) resulted in pine BAl increase from by approximately $0.9 \mathrm{~cm}^{2}$ in younger pine (60) up to $1.1 \mathrm{~cm}^{2}$ in older pine (110).

An increase in the proportion of deciduous trees resulted in both increase/decrease of pine BAI more significantly at FSs under different moisture regimes vs. different levels of fertility (Fig. 4). A 10\% increase in DTP resulted in an increase in pine BAI by approximately $9.0 \%$ at $\mathrm{W} 4$, a little lower at $\mathrm{W}_{2}$ and the lowest $4.6 \%$ at $\mathrm{W}_{1}$, while by only $4.8 \%$ at $\mathrm{N}_{2}$, a little lower at $\mathrm{N}_{3}$ and the lowest, only $1.0 \%$, at N4 FS. Age of pine stand had no significant effect on the increase in pine BAl with increasing DTP in mixed stands and made about $7-8 \%$ in middle aged and mature stands.

The most significant effect of deciduous trees on pine BAl was observed at $\mathrm{N} 2$ and W4 FSs. The positive effect of deciduous trees at $\mathrm{N}_{3}$ and $\mathrm{W}_{1} \mathrm{FSs}$, which dominate in Lithuania, was slightly lower. A negative effect of deciduous trees resulting in the reduction of pine BAI was established only at $\mathrm{N}_{1}$ and $\mathrm{W}_{3}$ FSs, not typical for pine growth in Lithuania.

Fig. S4 (Supplementary material) shows that a DTP up to approximately $50 \%$ in mesoeutrophic soil N2 FS resulted in the same pine BAI as in pure pine stands in eutrophic soils FS (N1). The basal area increment of pine trees was around $13 \mathrm{~cm}^{2}$ per year. On the other hand, DTP of up to $50 \%$, which increased pine BAI in oligotrophic (poor) fertility soils $\left(\mathrm{N}_{3}\right)$ by up to $9 \mathrm{~cm}^{2}$ per year, reduced pine BAI by a similar level in eutrophic soils ( $\mathrm{N} 1)$.

Such opposite effects of the proportion of deciduous tree species, mainly Betula spp., on pine growth should be taken into account in silvicultural measures for sustainable development of boreal or hemiboreal coniferous forest.

\section{Discussion}

\section{Main methodological approach of the study}

Forest inventory data collected based on rigorous statistical methods provide reliable data on forest productivity since the circle plots are the same size in all sampled areas and are evenly located, forming a tight network in the area of investigation. Caution should be exerted, however, with the use of such datasets to detect the effects of meteorology or new meteorological threats on pine boreal forest. Tree ring width data series are the most reliable as the accuracy of annual tree ring width data obtained from tree stem analysis is typically higher than DBH data obtained from permanent sample plots of national forest inventories (García 2005). Short time series and poor age records are mentioned among the most concerning problems, together with the fact that dendrometric data are often recorded with much lower precision (Sterba et al. 2014).

Tree rings are also widely used to understand the impact of climate change on forest carbon cycling, and to validate processbased models of forest productivity, where temporal variation of productivity is determined by large trees (Xu et al. 2019). Combining conventional forest inventory data and annual increment data based on increment cores of dominant trees in stands offers great potential to evaluate growth patterns under different forest conditions in relation to environmental factors. In this study, an evaluation of the capacity of Scots pine to adapt to climate change was undertaken on the basis of Lithuanian $\mathrm{Na}$ tional forest inventory (NFI) data on stand structure and productivity, supplemented with tree ring width series of single dominating pine trees. This methodological approach allowed to establish the main tendencies in BAl formation of pine trees under different FS conditions and to detect key meteorological parameters, which affect pine forests in Lithuania.

Radial growth of trees within forest stands greatly depends on the interactions between competition and environmental conditions (Piutti \& Cescatti 1997). According to the current state of knowledge, dominating tree parameters reflect well the productivity of a fully stocked evenaged stand because they are independent of density, or competition intensity (Skovsgaard \& Vanclay 2008), and therefore, are used as a measure of site productivity (Monserud \& Sterba 1996). Parameters of dominating trees are the key parameters in site index models (Pretzsch et al. 2002, Reed et al. 2003). They are also often included in forest development models used for the estimation of species mixing effects or of the effect of forestry measures, expressed through variation in stem radial growth (Sterba et al. 2014, Sharma et al. 2019).

It is essential to carefully consider tree sample design in dendrochronological analyses, in order to estimate precisely tree increment, their changes, and the effects of climate change, minimizing the sampling effort from more than 2000 permanent observation plots of Lithuanian national forest inventory net. We sampled from 1 up to 2-3 tree cores per plot to ensure reliable representation of mixed pine stand productivity and productivity variations during the last few decades, even though only one tree ring series per tree species was represented. The results confirmed our hypothesis on the relationship between the mean values of pine tree BAI (based on dendrochronological data of dominating single pine trees) and gross stand volume increment (based on NFI data). The Wilcoxon test for all species including Scots pine supported the null hypothesis ( $p=0.650-$ 0.972 ), meaning that there was no significant difference in paired series gathered using different methodologies, i.e., between the data collected within the frame of NFI and the data collected from treelevel dendrochronological investigation (Kulbokas et al. 2019). A regression model created with the NFI data on stand volume increment as the dependent variable and tree-level $\mathrm{BAl}$ as the independent variable was characterized by significant coefficients of determination exceeding $70 \%$.

To meet the objectives, $\mathrm{W}_{1}$ and N2 FSs were used as references for water and nutrient levels in forest stands as they were considered to represent best growing conditions for Scots pine in Lithuania. Every factor was compared against this reference to evaluate differences in chosen factor groups (soil moisture or nutrition). Such comparisons help to find factors that positively or negatively affect BAI at given soil moisture or nutrient levels.

To reduce $\mathrm{BAI}$ variation among the stands, standwise calibration was performed based on tree BA. It is known that BAl captures growth trends better than tree-ring width and avoids the need for data detrending (Biondi \& Qeadan 2008). However, in our model, significant relationships between BA and BAI remained, indicating direct effects of stem diameter and tree age on BAI. This relationship could be attributed to the effect of climate warming, when the observed increase in temperature had a more significant effect on the increase in BAl of the older and bigger pine trees than on the younger and thinner trees.

Much of data variability resided in the random effects. Differences between corresponding marginal $R^{2}$ (variance explained by fixed factors) and conditional $\mathrm{R}^{2}$ (variance explained by fixed and random factors) reflect how much variability is related to random effects (Tab. 2). Unstructured random components (tree and plot location together with tree id) were included into the models to account for subject-specific BAl variations through the nonlinear mixed-effects modeling approach. In the 
present study the introduction of these components helped to explain differences between different growth conditions that could not be accounted for otherwise. Such differences within or between plots of the same soil type may be due factors we did not account for in the model such as genetics or competition. Recently, this approach has been used to increase the prediction accuracy of forest growth models (Fu et al. 2018, Sharma et al. 2019). In such situations it is claimed that a mixedeffects modeling approach is the most appropriate, as it takes into account the hierarchical data structure and includes all the subject-specific variations, stochasticity, and randomness present in the data (Chapagain \& Sharma 2021). Inclusion of the parameters of dominating trees (BA) and pine stands (mixture, site condition, age) together with subject-specific random effects into the BAl models significantly increased the explanation of BAl variation and the biological importance of the models especially in stands of pine mixture with deciduous tree species, mainly Betula spp.

\section{Effect of deciduous tree proportion} (DTP) on pine stem BAI

Forest mixtures offer great potential for silviculture, not only due to the higher resilience and resistance to various biotic and abiotic climate-related disturbances but also due to higher productivity and capacity to mitigate risks associated with climate change (Pretzsch et al. 2015, Bouwman et al. 2021). However, their growth dynamics are often difficult to predict because species interactions vary with climatic and edaphic conditions, stand structure and forest management (Aldea et al. 2021).

DTP in pine stands had a beneficial effect that could be explained by better light distribution in the tree canopy and higher nutrient level in the upper soil horizon due to deciduous leaf litterfall. This result agrees well with findings on the beneficial effects of deciduous trees in pine stands, evidenced as increased adaptability of mixed stands to recent changes (Liang et al. 2016), and in some cases, increased productivity when compared to similar monospecies stands (Rio et al. 2016, Jactel et al. 2018).

Soil properties might affect the interaction between deciduous and pine trees. Jactel et al. (2018) reported that the relationship between biodiversity and productivity can become more positive or more negative under different soil conditions, especially with limited water or nutrient supply (Ratcliffe et al. 2017, Jucker et al. 2016). As availability of water increases, the availability of nutrients decreases, resulting in an increase in light competition (Pretzsch et al. 2014).

Maestre \& Cortina (2004) also claimed that when a limited resource is the only fundamental abiotic stress factor, facilitation could only occur when deciduous trees increased the availability of this re- source for the coniferous tree species. Such interactions might possibly be happening in the poorest peatland soils FSs, i.e., at combined $\mathrm{W}_{4}$ and $\mathrm{N}_{3}$ and $\mathrm{W}_{4}$ and N4 FSs, which could explain the increased pine growth at such sites when useful minerals are most likely scarce (oligotrophic FS). These relationships confirm results on very nutrient reach $\mathrm{N} 1$ and water regime interrupted drained W3 FS where deciduous trees reduced pine BAI.

The results on the mixture effect in pine forests revealed that the highest magnitude of changes in pine BAI was obtained applying the "Water" model (eqn. 1) and confirmed the statement that availability of water is a key parameter of pine productivity in hemi-boreal forest in northeastern europe (Pretzsch et al. 2014, Jactel et al. 2018).

Our results on the benefits of mixtures of pine and deciduous trees contribute to the knowledge that carefully designed mixed Scots pine stands could bring a wider range of ecosystem services and be more resilient than pure stands, while also increasing productivity (Jactel et al. 2018, Rio et al. 2016, Pretzsch et al. 2014, 2015).

Effect of meteorology on pine stem BAI Scots pine growth is affected by frost, heat and drought throughout Europe (Aldea et al. 2021). The radial growth responses of the eastern Baltic population of Scots pine showed explicit regional gradients depending on local climates, indicating gradual shifts in the effects of winter temperature and summer moisture regimes (Matisons et al. 2021).

The effect of June precipitation on BAI at FSs with different moisture regimes was not as significant as expected. Despite its positive and significant effect on BAI in almost all FSs, a negative effect of precipitation in drained peatland soil (W3) was detected with a slight decrease in BAI. At this $\mathrm{FS}$, a decrease in BAI with increasing proportion of deciduous trees in pine stands was observed, possibly due to light competition with faster growing deciduous trees like ash, alder or birch. Trees with lower average $\mathrm{DBH}$, but similar height were observed at the drained sites when compared to the other sites except for the peatland sites (W4 - Tab. 1). Similar results were obtained by Hökkä \& Groot (2011) with drained sites, as they found that growth might be limited by excess soil water in low stock stands that possibly had damaged drainage systems. An annual report of the Lithuanian Mineral and Mining Sector (Skrinskas et al. 2010) stated that $54 \%$ of drained sites are in bad working condition and $15 \%$ have insufficient drainage, mainly due to activity of ineffectively managed beaver communities. It is possible that the effect of higher precipitation in beaverdamaged stands resulted in episodes of waterlogged regime causing a stress reaction in pine trees.

On the other hand, changes in tree growth at northern latitudes is mainly limited by the availability of water in sandy soils (Michelot et al. 2012), making tree growth there more sensitive to climatic variation (Lebourgeois et al. 2010). Possibly, the effect of precipitation during June on BAl formation at FSs with lower water availability differed significantly in comparison with the effect observed at waterlogged soil FSs.

Our findings showed that the effect of precipitation in June on pine BAI was more significant than the effect of temperature in March in different nutrient levels, while the effect of temperature in March was more significant than the effect of precipitation in June in FSs with different moisture levels. These findings agreed with our earlier results showing negative effects of drought and positive effects of climate warming on pine basal area increment in locally or regionally polluted forest (Juknys et al. 2002, 2003, 2014, Augustaitis et al. 2015, 2018). No negative effect of increased temperature on pine BAI in the remaining months was established. Therefore increases in early spring temperature and precipitation amount during vegetation could promote Scots pine tree growth and overall yield of pine stands in Lithuania.

\section{Conclusions}

From our study we conclude that:

- an increase in mean temperature in March resulted in an increase in dominat ing pine tree BAI more significant than an increase in precipitation amount in the middle of the vegetation period, when intensity of this increase in older pine stand was higher than in younger ones; it is the key finding of the effect of climate warming on pine BAl in hemi-boreal forests;

- an increase in the proportion of deciduous trees in mixed pine stands had a positive effect on dominating pine tree BAI in typical for Scots pine growth FSs and most importantly in oligotrophic soil (N3) prevailing in Lithuania;

- in drained peatland soils (W3), an increase in precipitation during June and of the deciduous tree ratio in pine stands had a negative effect on dominating pine tree BAl; the same negative tendency was observed in the stands on eutrophic soil (N1);

- tree age had a significant effect only on relationships between dominating pine tree $\mathrm{BAI}$ and mean temperature in March; the effect of age on the relationships between pine tree BAl formation and precipitation amount was not significant;

- forestry treatments directed toward the increase of deciduous tree proportion in the most common normal or temporarily waterlogged meso-eutrophic and oligotrophic pine stands might increase not only the biodiversity of pine stands, but also their productivity, and could help the hemi-boreal pine forest adapt to and mitigate the new threats of climate warming. 


\section{Acknowledgments}

We would like to thank Dr. Peter Biber from the Munich Technical University for helping with the statistical analysis. This research was supported by the Forest Policy Group of the Ministry of Environment of the Republic of Lithuania.

\section{References}

Aldea J, Ruiz-Peinado R, Del Río $M$, Pretzsch $\mathrm{H}$, Heym M, Brazaitis $G$, Jansons A, Metslaid $M$, Barbeito I, Bielak K, Granhus A, Holm SO, Nothdurft A, Sitko R, Lof M (2021). Species stratification and weather conditions drive tree growth in Scots pine and Norway spruce mixed stands along Europe. Forest Ecology and Management 481: 118697. - doi: 10.1016/j.foreco.2020.118697 Augustaitis A (2007a). Pine sawfly (Diprion pini L.) - Related changes in Scots pine crown defoliation and possibilities of recovery. Polish Journal of Environmental Studies 16: 363-369.

Augustaitis A, Augustaitiene I, Cinga G, Mazeika J, Deltuvas R, Juknys R, Vitas A (2007b). Did the ambient ozone affect stem increment of Scots pines (Pinus sylvestris L.) on territories under regionnal pollution load? Step III of Lithuanian studies. Scientific World Journal 7: 58-66. - doi: 10.1100/tsw.2007.55

Augustaitis A, Augustaitiene I, Mozgeris G, Juknys R, Vitas A, Jasinevičiene D (2015). Growth patterns of scots pine (Pinus sylvestris L.) under the current regional pollution load in Lithuania. iForest 8: 509-516. - doi: 10.3832/ifor1267-007

Augustaitis A, Augustaitiene I, Baumgarten M, Bicenkiene S, Girgdiene R, Kulbokas G, Linkevičius E, Marozas V, Mikalajunas M, Mordas G, Mozgeris G, Petrauskas E, Pivoras A, Ulevičius V, Vitas A, Matyssek R (2018). Tree-ring formation as an indicator of forest capacity to adapt to the main threats of environmental changes in Lithuania. Science of the Total Environment 615: 1247-1261. - doi: 10.1016/j.scitotenv.2017.09. 169

Baillie MGL, Pilcher JR (1973). A simple cross-dating program for tree-ring research. Tree-Ring Bulletin 33: 7-14.

Biondi F, Qeadan F (2008). A theory-driven approach to tree-ring standardization: defining the biological trend from expected basal area increment. Tree Ring Research 64 (2): 81-96. doi: 10.3959/2008-6.1

Bouwman M, Forrester DI, Den Ouden J, Nabuurs GJ, Mohren GMJ (2021). Species interactions under climate change in mixed stands of Scots pine and pedunculate oak. Forest Ecology and Management 481: 118615. - doi: 10.1016/ j.foreco.2020.118615

Burnham KP, Anderson DR (2002). Model Selection and Inference: a practical information-theoretic approach ( $2^{\text {nd }}$ edn). Springer-Verlag, New York, USA, pp. 488. - doi: 10.1007/b97636

Chapagain TR, Sharma RP (2021). Modeling form factors for sal (Shorea robusta Gaertn.) using tree and stand measures, and random effects. Forest Ecology and Management 482: 118807. doi: 10.1016/j.foreco.2020.118807

Cook ER, Kairiukstis LA (1990). Methods of dendrochronology - Applications in the environmental sciences. Springer, Dordrecht, Netherlands, pp. 97-162. - doi: 10.1007/978-94-0157879-0
Daly C, Gibson WP, Taylor GH, Johson GL, Pasteris $P$ (2002). A knowledge-based approach to the statistical mapping of climate. Climate Research 22: 99-113. - doi: 10.3354/cro22099

De Vries W, Dobbertin MH, Solberg S, Van Dobben HF, Schaub M (2014). Impacts of acid deposition, ozone exposure and weather conditions on forest ecosystems in Europe: an overview. Plant and Soil 380: 1-45. - doi: 10.1007/s11104014-2056-2

Eckstein D, Krause C, Bauch J (1989). Dendroecological investigation of spruce trees (Picea abies (L.) Karst.) of different damage and canopy classes. Holzforschung 43: 411-417. - doi: 10.1515/hfsg.1989.43.6.411

Forrester DI, Albrecht AT (2014). Light absorption and light-use efficiency in mixtures of Abies alba and Picea abies along a productivity gradient. Forest Ecology and Management 328: 94-102. - doi: 10.1016/j.foreco.2014.05.026

Fu L, Le X, Sharma RP, Li H, Zhu G, Hong L, You L, Duan G, Guo H, Lei Y, Li Y, Tang S (2018). Comparing height-age and height-diameter modelling approaches for estimating site productivity of natural uneven-aged forests. Forestry 91: 419-433. - doi: 10.1093/forestry/cpx049

Garant MP, Huang JG, Izquierdo G, Raulier F, Bernier P, Berninger $F$ (2009). Use of tree rings to study the effect of climate change on trembling aspen in Quebec. Global Change Biology 16: 2039-2051. - doi: 10.1111/j.1365-2486.2009.020 48.x

García O (2005). Comparing and combining stem analysis and permanent sample plot data in site index models. Forest Science 51: 277-283. [online] URL: http://academic.oup.com/forestsci ence/article/51/4/277/4617597

Girardin MP, Raulier F, Bernier PY, Tardif JC (2008). Response of tree growth to a changing climate in boreal central Canada: a comparison of empirical, process-based, and hybrid modelling approaches. Ecological Modelling 213: 209228. - doi: 10.1016/j.ecolmodel.2007.12.010

Hökkä H, Groot A (2011). An individual-tree basal area growth model for black spruce in secondgrowth peatland stands. Canadian Journal of Forest Research 29: 621-629. - doi: 10.1139/x99032

IPCC (2014). Climate change 2014: synthesis report. In: "Contribution of Working Groups I, II and III to the Fifth Assessment Report" (Pachauri RK, Meyer LA eds). Intergovernmental Panel on Climate Change - IPCC, Geneva, Switzerland, pp. 151.

Jactel H, Gritti E, Drössler L, Forrester D, Mason W, Morin X, Pretzsch H, Castagneyrol B (2018). Positive biodiversity-productivity relationships in forests: climate matters. Biology Letters 14: 20170747. - doi: 10.1098/rsbl.2017.0747

Jucker T, Avacariei D, Barnoaiea I, Duduman G, Bouriaud O, Coomes DA (2016). Climate modulates the effects of tree diversity on forest productivity. Journal of Ecology 104: 388-398. - doi: 10.1111/1365-2745.12522

Juknys R, Stravinskiene V, Vencloviene J (2002). Tree-ring analysis for the assessment of anthropogenic changes and trends. Environmental Monitoring and Assessment 77: 81-97. - doi: 10.1023/A:1015718519559

Juknys R, Vencloviene J, Stravinskiene V, Augustaitis A, Bartkevičius E (2003). Scots pine (Pinus sylvestris L.) growth and condition in a polluted environment: from decline to recovery. Environmental Pollution 125: 205-212. - doi: 10.1016/ S0269-7491(03)00070-8

Juknys R, Augustaitis A, Vencloviene J, Kliučius A, Adomas V, Bartkevičius E, Jurkonis N (2014). Dynamic response of tree growth to changing environmental pollution. European Journal of Forest Research 133: 713-724. - doi: 10.1007/s103 42-013-0712-3

Kairiukstis L, Grigaliunas J, Skuodiene L, Stravinskiene V (1987). Physiological and dendrochronological indications of forest decline and their application for monitoring. In: “Forest Decline and Reproduction: Regional and Global Consequences" (Kairiukstis L, Nilsson S, Straszak A eds). IIASA, Luxemburg, pp. 151-169.

Kulbokas G, Jurevičiene V, Kuliesis A, Augustaitis A, Petrauskas E, Mikalajunas M, Vitas A, Mozgeris $G$ (2019). Fluctuations in gross volume increment estimated by the Lithuanian National Forest Inventory compared with annual variations in single tree increment. Baltic Forestry 25: 273-280. - doi: 10.4649o/vol25iss2pp273

Kuliešis A, Kasperavičius A, Kulbokas G (2016). Lithuania. In: "National Forest Inventories - Assessment of Wood Availability and Use" (Vidal C, Alberdi I, Hernandez L, Redmond J eds). Springer International Publishing, Cham, Switzerland, pp. 521-547. - doi: 10.1007/978-3-319-440 15-6_28

Lebourgeois F, Rathgeber CBK, Ulrich E (2010). Sensitivity of French temperate coniferous forests to climate variability and extreme events (Abies alba, Picea abies and Pinus sylvestris). Journal of Vegetation Science 21: 364 376. - doi: 10.1111/j.1654-1103.2009.01148.x

Liang J, Crowther TW, Picard N, Wiser S, Zhou M, Alberti G, Schulze ED, Mcguire AD, Bozzato F, Pretzsch $\mathrm{H}$, de-Miguel S, Paquette A, Herault B, Scherer-Lorenzen $M$, Barrett $C B$, Glick HB, Hengeveld GM, Nabuurs GJ, Pfautsch S, Viana H, Vibrans AC, Ammer C, Schall P, Verbyla D, Tchebakova N, Fischer M, Watson JV, Chen HY, Lei X, Schelhaas MJ, Lu H, Gianelle D, Parfenova El, Salas C, Lee E, Lee B, Kim HS, Bruelheide H, Coomes DA, Piotto D, Sunderland T, Schmid B, Gourlet-Fleury S, Sonke B, Tavani R, Zhu J, Brandl S, Vayreda J, Kitahara F, Searle EB, Neldner VJ, Ngugi MR, Baraloto C, Frizzera L, Ba azy R, Oleksyn J, Zawi a-Nied wiecki T, Bouriaud O, Bussotti F, Finer L, Jaroszewicz B, Jucker T, Valladares F, Jagodzinski AM, Peri PL, Gonmadje C, Marthy W, Obrien T, Martin EH, Marshall AR, Rovero F, Bitariho R, Niklaus PA, Alvarez-Loayza P, Chamuya N, Valencia R, Mortier F, Wortel $\mathrm{V}$, Engone-Obiang NL, Ferreira LV, Odeke DE, Vasquez RM, Lewis SL, Reich PB (2016). Positive biodiversity-productivity relationship predominant in global forests. Science 354 (6309): aaf8957. - doi: 10.1126/science.aaf8 957

Macias M, Andreu L, Bosch O, Camarero JJ, Gutiérrez E (2006). Increasing aridity is enhancing silver fir Abies alba (Mill.) water stress in its south-western distribution limit. Climate Change 79: 289-313. - doi: 10.1007/s10584-0069071-0

Maestre FT, Cortina J (2004). Do positive interactions increase with abiotic stress? A test from a semi-arid steppe. Royal Society Biological sciences London B271: S331-S333. - doi: 10.1098/ 
rsbl.2004.0181

Matisons R, Elferts D, Krišans O, Schneck V, Gartner H, Bast A, Wojda T, Kowalczyk J, Jansons A (2021). Non-linear regional weather-growth relationships indicate limited adaptability of the eastern Baltic Scots pine. Forest Ecology and Management 479: 118600. - doi: 10.1016/j.for eco.2020.118600

McMillan AMS, Winston GC, Coulden ML (2008). Age-dependent response of boreal forest to temperature and rainfall variability. Global Change Biology 14 (8): 1904-1916. - doi: 10.1111/j. 1365-2486.2008.01614.x

Mensah AA, Holmström E, Petersson H, Nyström $\mathrm{K}$, Mason EG, Nilsson U (2021). The millennium shift: investigating the relationship between environment and growth trends of Norway spruce and Scots pine in northern Europe. Forest Ecology and Management 481: 118727. - doi: 10.1016/j.foreco.2020.118727

Michelot A, Breda N, Damesin C, Dufrene E (2012). Differing growth responses to climatic variations and soil water deficits of Fagus sylvatica, Quercus petraea and Pinus sylvestris in a temperate forest. Forest Ecology and Management 265: 161-171. - doi: 10.1016/j.foreco.2011.10. 024

Monserud RA, Sterba H (1996). A basal area increment model for individual trees growing in even- and uneven-aged forest stands in Austria. Forest Ecology and Management 80: 57-80. doi: 10.1016/0378-1127(95)03638-5

Nakagawa S, Schielzeth H (2013). A general and simple method for obtaining $\mathrm{R}^{2}$ from generalized linear mixed-effects models. Methods in Ecology and Evolution 4: 133-142. - doi: 10.1111/j. 2041-210x.2012.00261.x

Nellemann C, Thomsen M (2001). Long-term changes in forest growth: potential effects of nitrogen deposition and acidification. Water, Air, and Soil Pollution 128 (3/4): 197-205. - doi: 10.1023/A:1010318800180

Ols C, Kalas IH, Drobyshev I, Söderström L, Hofgaard A (2019). Spatiotemporal variation in the relationship between boreal forest productivity proxies and climate data. Dendrochronologia 58 (116): 125648. - doi: 10.1016/j.dendro.2019.12 5648

Pinheiro J, Bates D, Debroy S, Sarkar D (2018). nlme: linear and nonlinear mixed effects models. R Package Version 3:1-137.2018, web site. [online] URL: http://CRAN.R-project.org/packag e=nlme

Piovesan G, Biondi F, Filippo AD, Alessandrini A, Maugeri $M$ (2008). Drought-driven growth reduction in old beech (Fagus sylvatica L.) forests of the central Apennines, Italy. Global Change Biology 14: 1265-1281. - doi: 10.1111/j.1365-2486. 2008.01570.x

Piutti E, Cescatti A (1997). A quantitative analysis of the interactions between climatic response and intraspecific competition in European beech. Canadian Journal of Forest Research 27: 277-284. - doi: 10.1139/x96-176

Pretzsch H, Biber P, Dursky J (2002). The single tree-based stand simulator SILVA: construction, application and evaluation. Forest Ecology and Management 162: 3-21. - doi: 10.1016/S0378-1127
(02)00047-6

Pretzsch H, Schütze G, Uhl E (2013). Resistance of european tree species to drought stress in mixed versus pure forests: evidence of stress release by inter-specific facilitation. Plant Biology 15: 483-495. - doi: 10.1111/j.1438-8677.2012. 00670.x

Pretzsch H, Biber P, Schütze G, Uhl E, Rötzer T (2014). Forest stand growth dynamics in Central europe have accelerated since 1870. Nature Communications 5 (1): 1065. - doi: 10.1038/ncom ms5967

Pretzsch H, Rio M, Ammer C, Avdagic A, Barbeito I, Bielak K, Brazaitis G, Coll L, Dirnberger G, Drössler L (2015). Growth and yield of mixed versus pure stands of Scots pine (Pinus sylvestris L.) and european beech (Fagus sylvatica L.) along a gradient of productivity through europe. European Journal of Forest Research 134: 927-947. - doi: 10.1007/s10342-015-0900-4

Pretzsch H (2020). The course of tree growth. Theory and reality. Forest Ecology and Management 478: 118508. - doi: 10.1016/j.foreco.2020. 118508

R Development Core Team (2018). R: a language and environment for statistical computing. $\mathrm{R}$ Foundation for Statistical Computing, Vienna, Austria. [online] URL: http://www.r-project.org Ratcliffe S, Wirth C, Jucker T, Van Der Plas F, Scherer-Lorenzen $M$, Verheyen K, Allan E, Benavides $R$, Bruelheide $H$, Ohse $B$ (2017). Biodiversity and ecosystem functioning relations in European forests depend on environmental context. Ecology Letters 20: 1414-1426. - doi: 10.1111/ ele.12849

Reed DD, Jones EA, Tome M, Araujo MC (2003). Models of potential height and diameter for Eucalyptus globulus in Portugal. Forest Ecology and Management 172: 191-198. - doi: 10.1016/ S0378-1127(01)00802-7

Reich PB, Oleksyn J (2008). Climate warming will reduce growth and survival of Scots pine except in the far north. Ecology Letters 11 (6): 588-597. - doi: 10.1111/j.1461-0248.2008.01172.x Rio M, Pretzsch H, Alberdi I, Bielak K, Bravo F, Brunner A, Condes S, Ducey M, Fonseca T, Lüpke $N$ (2016). Characterization of the structure, dynamics, and productivity of mixed-species stands: review and perspectives. European Journal of Forest Research 135: 23-49. - doi: 10.1007/s10342-015-0927-6

Rubio-Cuadrado A, Camarero JJ, Gomez C, Canellas I, Aullo-Maestro I, Gil L, Montes F (2020). Scots pine plantations growth adaptation to climate warming in locations at the southernmost distribution limit of the species. Dendrochronologia 63: 125745. - doi: 10.1016/j.den dro.2020.125745

Schlechtriem M (2019). Mapped: impact of climate on European countries. GREENMATCH, UK Blog Awards, UK, web site. [online] URL: http://www.greenmatch.co.uk/blog/2019/04/cli mate-change-europe

Schweingruber FH (1996). Tree rings and environment: dendroecology. Paul Haupt Publishers, Bern, Switzerland, pp. 609. [online] URL: http://www.cabdirect.org/cabdirect/abstract/19 980602476
Seidling W, Ziche D, Beck W (2012). Climate responses and interrelations of stem increment and crown transparency in Norway spruce, Scots pine, and common beech. Forest Ecology and Management 284: 196-204. - doi: 10.1016/j. foreco.2012.07.015

Sharma RP, Stefancik I, Vacek Z, Vacek S (2019). Generalized nonlinear mixed-effects individual tree diameter increment models for beech forests in Slovakia. Forests 10: 451-475. - doi: 10.3390/f10050451

Skovsgaard JP, Vanclay JK (2008). Forest site productivity: a review of the evolution of dendrometric concepts for even-aged stands. Forestry 81: 12-31. - doi: 10.1093/forestry/cpmo41 Skrinskas S, Gasiuniene VE, Laurinavicius A, Podagelis I (2010). Lithuanian mineral resources, their reserves and possibilities for their usage in road building. The Baltic Journal of Road and Bridge Engineering 5 (4): 218-228. doi: $10.3846 /$ bjrbe.2010.30

Spiecker H (1999). Overview of recent growth trends in European forests. Water, Air, and Soil Pollution 116 (1/2): 33-46. - doi: 10.1023/A:10052 05515952

Sterba H, Del Rio M, Brunner A, Condes S (2014). effect of species proportion definition on the evaluation of growth in pure vs. mixed stands. Forest Systems 23: 547-559. - doi: 10.5424/fs/ 2014233-06051

Toochi EC (2017). Forest and environment: developments in global change ecology. Forestry Research and Engineering 1 (3): 100-105. [online] URL: http://www.researchgate.net/publication/ 325627538

Xu K, Wang $X$, Liang $P$, Wu Y, An $\mathrm{H}$, Sun $\mathrm{H}$, Wu $\mathrm{P}$, Wu X, Li Q, Guo X, Wen X, Han W, Liu Ch Fan D (2019). A new tree-ring sampling method to estimate forest productivity and its temporal variation accurately in natural forests. Forest Ecology and Management 433: 219-227. - doi: 10.101 6/j.foreco.2018.10.066

\section{Supplementary Material}

Fig. S1 - Effect of the mean temperature in March and precipitation amount during June on annual BAI at FSs with different moisture regimes, i.e., "Water" FS group.

Fig. S2 - Effect of mean temperature in March and precipitation amount during June on the annual BAI for the considered 20-year period at FSs with different nutrient levels, i.e., "Nutrients" FS group.

Fig. S3 - Effect of temperature in March and precipitation during June on BAI formation of pine trees in different aged FS groups.

Fig. S4 - Effect of the proportion of pine trees in mixed pine stands on pine BAI formation at FSs with different moisture regimes, "Water", and fertility levels, "Nutrients".

Link: Augustaitiene_3703@supplo01.pdf 